\title{
Faculty Perceptions about Teaching Online: Exploring the Literature Using the Technology Acceptance Model as an Organizing Framework
}

\author{
Nancy Pope Wingo, Nataliya V. Ivankova, Jacqueline A. Moss \\ The University of Alabama at Birmingham
}

\begin{abstract}
Academic leaders can better implement institutional strategic plans to promote online programs if they understand faculty perceptions about teaching online. An extended version of a model for technology acceptance, or TAM2 (Venkatesh \& Davis, 2000), provided a framework for surveying and organizing the research literature about factors that have influenced faculty's adoption of online delivery methods for courses and their willingness to continue to teach online. This paper presents the results of a synthesis of 67 empirical studies about faculty teaching online published between 1995 and 2015, using TAM2 constructs as an organizing framework. This validated model provided a lens for understanding research about faculty perceptions of the user-friendliness and ease of use of technology for online course delivery, as well as the overall experience of teaching online. Studies in this review revealed concerns among faculty regarding their perceived barriers to student success in online classes, uncertainty about their image as online instructors, technical support needs, and their desire for reasonable workload and manageable class enrollments in online classes.
\end{abstract}

Keywords: online faculty, online teaching, Technology Acceptance Model, literature review, faculty adoption

Wingo,N. P., Ivankova, N. V., \& Moss, J. A. (2017) Faculty perceptions about teaching online: exploring the literature using the technology acceptance model as an organizing framework, Online Learning 21(1), 15-35. doi: 10.10.24059/olj.v21i1.761

\section{Introduction}

Higher education faculty in the United States are increasingly being asked to teach online (Allen \& Seaman, 2015). Yet faculty may be reluctant to embrace different forms of online teaching, due to fear of change, concerns about the reliability of technology, skepticism about student outcomes in online learning environments, workload issues, and other factors (Bacow et al. 2012; Betts \& Heaston, 2014; Bolliger \& Wasilik, 2009; McQuiggan, 2012). Fostering faculty's acceptance of online delivery methods is critical for institutions that consider online learning to be a key part of their strategic plan; to accomplish this, administrators need to understand how faculty perceive teaching online and what factors shape those perceptions. 
The Technology Acceptance Model (TAM) (Davis, 1989) has been used for decades to explain how users accept new technologies. An extended version of the original model, "TAM2" (Venkatesh \& Davis, 2000), confirmed the effects of various factors on key constructs of the original model. Because it illustrates influences on technology acceptance in a clearly structured format, this validated model can provide a framework to better understand faculty's perceptions about teaching online. Despite its utility for understanding acceptance of new technology by the users, the TAM2 has not been applied to systematically study faculty acceptance of technology to deliver online courses. This paper addresses this gap and presents the results of the synthesis of the research literature regarding faculty perceptions about teaching online, using constructs in the TAM2 (Venkatesh \& Davis, 2000) as an organizing framework.

\section{Theoretical Framework}

We used a model of technology acceptance by users in organizations, validated by Venkatesh and Davis (2000) and based on the Technology Acceptance Model (TAM) (Davis, 1989) to guide the review of research literature that explored factors influencing faculty's perceptions of online teaching. We chose this model because it includes factors regarding users' technical experiences and their perceptions about how using technology might affect their status in an organization, providing a broad scope for surveying research about faculty's experiences as online instructors. A meta-analysis by King and He (2006) of 88 studies in different fields determined that the TAM was a "powerful and robust predictive model" (p. 751) to understand technology acceptance of users in various contexts. The original TAM is an empirically validated framework initially developed by Davis (1989) to explain end users' willingness to use new technologies in organizations. Its two key constructs are perceived usefulness (PU), or the degree to which a person believes a technology will improve his or her job performance, and perceived ease of use (PEU), or the amount of effort a person believes he or she will need to expend to master that technology.

The TAM was developed further when researchers sought to understand determinants of PEU (Venkatesh \& Davis, 1996) and PU (Venkatesh \& Davis, 2000). Venkatesh and Davis (1996) found that users' computer self-efficacy significantly affected PEU both before and after exposure to a technological system. They later explored the determinants of PU over four longitudinal studies at various sites and found that PU was significantly affected by "social influence processes" (subjective norm, voluntariness, and image) and "cognitive instrumental processes" (job relevance, output quality, result demonstrability, and perceived ease of use) (Venkatesh \& Davis, 2000, p. 187). The resulting model, or “TAM2,” (Venkatesh \& Davis, 2000), showed a more detailed relationship among various factors that influenced technology acceptance. The updated model continued to be used by researchers in different fields; in fact, Marangunić and Granić (2015) concluded, after a review of 85 publications using the TAM model, that the "TAM has evolved to become the key model in understanding the predictors of human behavior toward potential acceptance or rejection of the technology" (p. 92).

Figure 1 illustrates the TAM2 model with its two key constructs (PU and PEU) and shows the various factors found to influence PU (Venkatesh \& Davis, 2000). These factors included the subjective norm, or users' perceptions of whether others in an organization believed they should use a technological system. The subjective norm was moderated by whether users 
had prior experience using the technology, and whether using it was mandatory or voluntary in an organization.The subjective norm also influenced a user's perceptions of how his or her image might be affected as a result of using technology. Other factors influencing PU included job relevance, or user's perceptions of how a technological system could help them accomplish significant goals; output quality, or the quality of technology needed to accomplish specific tasks; and result demonstrability, or the perceived tangible results and benefits of using a technological system. Each of these factors will be discussed in more detail further in this article.

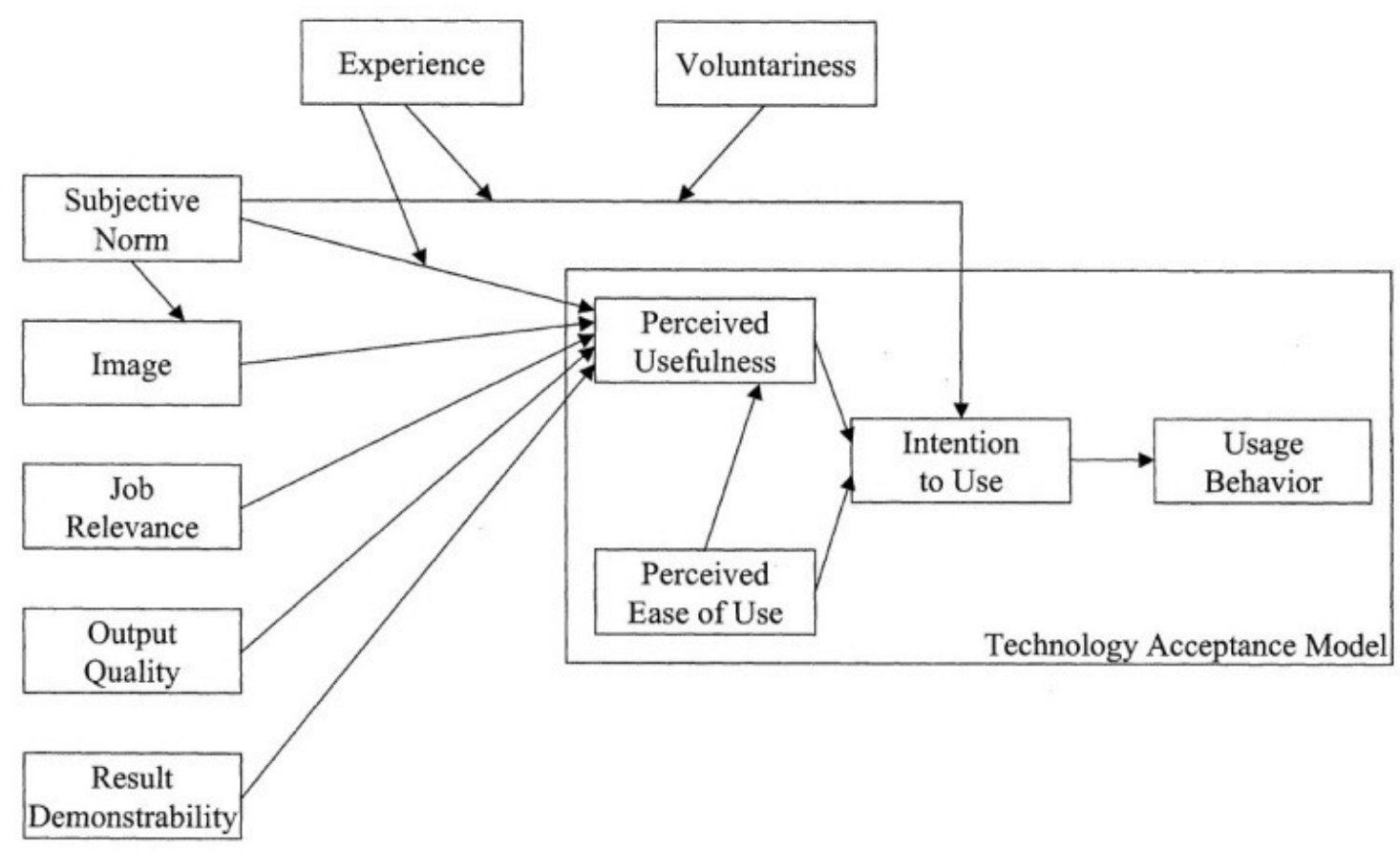

Figure 1. TAM2. Reprinted by permission, (Viswanath Venkatesh, Fred D. Davis), A Theoretical Extension of the Technology Acceptance Model: Four Longitudinal Field Studies, Management Science, 46, 2. Copyright (2000). The Institute for Operations Research and the Management Sciences, 5521 Research Park Drive, Suite 200, Catonsville, Maryland 21228 USA.

\section{Methods}

To explore empirical literature regarding faculty teaching online in the context of technology acceptance models, a search for studies that used the TAM or TAM2 in various disciplines was first conducted to gain a broader understanding of the applications of these models. Then, the search was narrowed to studies that used either of the models as theoretical frameworks for the experience of teaching online. After finding few studies meeting these criteria, the search was adjusted further to explore research that addressed specific elements of technology acceptance and adoption outlined in the TAM2 model in terms of teaching online, even if the authors had not used constructs of the model as a framework. Reviewing the literature in this manner allowed for a fuller picture of numerous factors related to faculty experiences in teaching online that have been explored by researchers, although they may not have explicitly 
stated the use of the TAM or TAM2 models. The procedures and results of those searches are discussed in more detail in the following sections.

\section{Searching for Research Applying the TAM to Various Disciplines}

Many researchers have applied some version of the TAM to various disciplines over the years. To understand the extent of its application, we searched empirical literature, using the terms "Technology Acceptance Model” or "TAM" in three databases: Academic Search Premier, ERIC, and Education Full Text (H. W. Wilson). The search yielded over 14,000 results. The same search terms in Google Scholar returned over 44,000 possible articles. Obviously, this model is popular for providing a framework for technology research, yet it also has a broad range of possible applications. To determine the application of the TAM by discipline, we narrowed our search to major journals in various fields that were likely to be concerned with technology acceptance, again using the search terms "Technology Acceptance Model” or "TAM." Results showed significantly more research rooted in the TAM in business than in other disciplines: Business Search Premier = 124 (59\% of total); Education Full Text = 34 (16\% of total); Library/Information Science/Technology Abstracts = 32 (15\% of total); and CINAHL Plus with Full Text $=20$ (9.5\% of total).

These numbers were not surprising, since the models' developers were business professors. Yet in the twenty-first century, with technology use permeating so many fields, the TAM might be increasingly used to better understand technology acceptance in any discipline. In fact, a statistical meta-analysis of TAM constructs performed by King and He (2006) across 88 empirical articles in the social sciences led the authors to conclude that the TAM was "a valid and robust model that has been widely used, but which potentially has wider applicability" (p. 740).

\section{Searching for Research Applying the TAM to Online Teaching}

To understand more about the application of the TAM in higher education, specifically concerning technology acceptance among faculty teaching online, we combined the search terms “Technology Acceptance Model” and "TAM" in various combinations with "online," "distance education," "faculty," and "instructors." Using these search terms in Academic Search Premier, CINAHL Plus with Full Text, ERIC, and Education Full Text (H. W. Wilson), we found only three articles from peer-reviewed journals that specifically applied the TAM to higher education faculty who were teaching in an online environment (Alsofyani, Aris, Eynon, \& Majid, 2012; Gibson, Harris, \& Colaric, 2008; Huang, Deggs, Jabor, \& Machtmes, 2011). A search on Google Scholar using “Technology Acceptance Model," "faculty,” and “online” yielded 598 results, but a scan of these abstracts again revealed that most of the studies were using data about students or were focused on marketing or online employee training programs. The Google Scholar search did reveal two additional empirical articles that used the TAM to better understand faculty's intentions to accept online education (Stewart, Bachman, \& Johnson, 2010; Wang \& Wang, 2009).

To complete the search, we first examined 102 different articles about faculty who teach online that we had collected from various search engines since 2007, searching for themes and keywords that related to constructs in the TAM2, even though they had not specifically mentioned the TAM2. We then conducted searches for other articles specifically related to each 
construct, pairing terms such as "computer self-efficacy" and "job relevance” with "online," "distance education," "faculty,” and "instructors.”

\section{Data Analysis}

Our combined searches yielded 67 empirical studies about faculty teaching online published between 1995 and 2015. To analyze these articles, we first made a list of construct components and their descriptions from the TAM2 model. We then carefully read each article, making notes about the reported findings that reflected various TAM2 construct components. This process revealed that these articles addressed issues that were described by at least one construct in the TAM2 model, even though they did not use the TAM2 model explicitly. We then organized all studies in a table grouped by the TAM2 construct components and developed short summaries of the major results that reflected these components. These 67 articles revealed a fuller picture of faculty's inclinations about technology adoption for online learning. Table 1 (below) shows all articles $(\mathrm{N}=67)$ included in this literature review with summarized findings that aligned with TAM2 constructs.

In our analysis of these articles, we did not attempt to make significant distinctions between "faculty acceptance" and "faculty satisfaction." In making this decision, we drew from a conceptualization of faculty satisfaction by Hagedorn (2000), illustrating disengagement at one end of a continuum, acceptance or tolerance in the middle, and job appreciation or engagement at the other end. This continuum suggested that faculty satisfaction would occur only after faculty had accepted some aspect of teaching online.

\section{Results}

We organized this review according to each construct in the model, beginning with studies that addressed faculty's PEU of technology for online course delivery and then exploring the various determinants of PU.

Table 1

Articles Reviewed in this Study, Aligned with TAM2 Constructs and Major Findings

TAM2 $\quad$ Studies Referenced $\quad$ Major Findings

Construct

Perceived ease of use (PEU)
Bolliger \& Wasilik (2009) Christianson, Tiene, \& Luft (2002)

Compeau \& Higgins (1995)

Conceição (2006)

DeGagne \& Walters (2010)

Green, Alejandro, \& Brown

(2009)

Osika, Johnson, \& Buteau

(2009)

Panda \& Mishra (2007)
Faculty were less satisfied with teaching online when they had technical problems.

Faculty who were more confident about their technical skills were more willing to teach online.

Faculty who were more skilled with technology were more satisfied with teaching online.

Faculty valued continuing education, even when 


\begin{tabular}{|c|c|c|}
\hline & $\begin{array}{l}\text { Ryan, Hodson-Carlton, \& } \\
\text { Ali (2005) } \\
\text { Shea (2007) } \\
\text { Shea, Pickett, \& Li (2005) } \\
\text { Tabata \& Johnsrud (2008) } \\
\text { Zhen, Garthwait, \& Pratt } \\
\text { (2008) }\end{array}$ & they were skilled online instructors. \\
\hline $\begin{array}{l}\text { Subjective } \\
\text { norm }\end{array}$ & $\begin{array}{l}\text { Allen \& Seaman (2012b) } \\
\text { Allen \& Seaman (2015) } \\
\text { Betts \& Heaston (2014) } \\
\text { Chapman (2011) } \\
\text { Dooley \& Murphrey (2000) } \\
\text { Huang, Deggs, Jabor, \& } \\
\text { Machtmes (2011) } \\
\text { Lee (2001) } \\
\text { Maguire (2009) } \\
\text { Orr, Williams, \& } \\
\text { Pennington (2009) } \\
\text { Wang \& Wang (2009) } \\
\text { Wickersham \& McElhany } \\
\text { (2010) }\end{array}$ & $\begin{array}{l}\text { Faculty did not view online education } \\
\text { with the same optimism that administrators did. } \\
\text { Faculty desired clearer statements of institutional } \\
\text { goals and policies regarding online education. } \\
\text { Faculty teaching online needed strong institutional } \\
\text { support in various forms. }\end{array}$ \\
\hline Voluntariness & $\begin{array}{l}\text { Betts (2009) } \\
\text { Dooley \& Murphrey (2000) } \\
\text { Hixon, Barczyk, } \\
\text { Buckenmeyer, \& } \\
\quad \text { Feldman (2011) } \\
\text { Jacobsen (2000) } \\
\text { Lackey (2011) } \\
\text { McQuiggan (2012) } \\
\text { Shea (2007) }\end{array}$ & $\begin{array}{l}\text { Motivating faculty to teach online required different } \\
\text { strategies, depending on whether faculty were } \\
\text { required to teach online or chose to do so. } \\
\text { Training faculty to teach online could promote } \\
\text { faculty satisfaction, despite whether teaching } \\
\text { online was mandatory or voluntary. }\end{array}$ \\
\hline Experience & $\begin{array}{l}\text { Allen \& Seaman (2012a) } \\
\text { Orr et al. (2009) } \\
\text { Ryan et al. (2005) } \\
\text { Seaman (2009) } \\
\text { Shea et al. (2005) } \\
\text { Ulmer, Watson, \& Derby } \\
\text { (2007) }\end{array}$ & $\begin{array}{l}\text { Faculty who had taught online were more } \\
\text { positive about the effectiveness of online teaching. } \\
\text { Faculty who had taught online were more willing } \\
\text { to continue to teach online. }\end{array}$ \\
\hline Image & $\begin{array}{l}\text { Alexander, Polyakova- } \\
\text { Norwood, Johnston, } \\
\quad \text { Christensen, \& Loquist } \\
\text { (2003) } \\
\text { Allen \& Seaman(2012a) } \\
\text { Allen \& Seaman (2013) } \\
\text { Allen \& Seaman (2015) } \\
\text { Bacow, Bowen, Guthrie, } \\
\text { Lack, \& } \\
\quad \text { Long (2012) }\end{array}$ & $\begin{array}{l}\text { Faculty had concerns about how teaching online } \\
\text { would affect their image. } \\
\text { Faculty worried that teaching online would } \\
\text { negatively affect their promotion and tenure process. } \\
\text { Faculty were unsure about how their teaching in online } \\
\text { courses would be assessed. } \\
\text { Faculty were more negative about the legitimacy }\end{array}$ \\
\hline
\end{tabular}




\begin{tabular}{|c|c|c|}
\hline & $\begin{array}{l}\text { Christianson et al. (2002) } \\
\text { Dooley \& Murphrey (2000) } \\
\text { Gaytan (2009) } \\
\text { Green et al. (2009) } \\
\text { Mason et al. (2010) } \\
\text { McQuiggan (2012) } \\
\text { Orr et al. (2009) } \\
\text { Shea (2007) } \\
\text { Stewart et al. (2010) } \\
\text { Ulmer et al. (2007) }\end{array}$ & of online education than administrators were. \\
\hline Job relevance & $\begin{array}{l}\text { Allen \& Seaman (2012a) } \\
\text { Bacow et al. (2012) } \\
\text { Bolliger \& Wasilik (2009) } \\
\text { Chao, Saj, \& Hamilton } \\
\text { (2010) } \\
\text { DeGagne \& Walters (2010) } \\
\text { Gibson, Harris, \& Colaric } \\
\text { (2008) } \\
\text { Haber \& Mills (2008) } \\
\text { Jaschik \& Lederman (2014) } \\
\text { Johnson (2008) } \\
\text { McQuiggan (2012) } \\
\text { Orr et al. (2009) } \\
\text { Osborne, Kriese, Tobey, \& } \\
\text { Johnson (2009) } \\
\text { Panda \& Mishra (2007) } \\
\text { Ryan et al. (2005) } \\
\text { Seaman (2009) } \\
\text { Shea et al. (2005) } \\
\text { Shovein, Huston, Fox, \& } \\
\text { Damazo (2005) } \\
\text { Stewart et al. (2010) }\end{array}$ & $\begin{array}{l}\text { Faculty were concerned about interacting with } \\
\text { students in online courses. } \\
\text { Faculty valued collaboration to design } \\
\text { online courses that were student-centric. } \\
\text { Faculty were more satisfied teaching online } \\
\text { when they believed students were achieving } \\
\text { learning outcomes }\end{array}$ \\
\hline Output quality & $\begin{array}{l}\text { Adkins, Kenkel, \& Lim } \\
\text { (2005) } \\
\text { Arend (2009) } \\
\text { Arif (2001) } \\
\text { Bacow et al. (2012) } \\
\text { Bolliger \& Wasilik (2009) } \\
\text { Chapman, Davis, Toy, \& } \\
\text { Wright (2004) } \\
\text { Green et al. (2009) } \\
\text { Grijalva, Nowell, \& } \\
\text { Kerkvliet (2006) } \\
\text { Haber \& Mills (2008) } \\
\text { Harmon, Lambrinos, \& } \\
\text { Buffolino (2010) } \\
\text { King, Guyette, \& } \\
\text { Piotrowski (2009) } \\
\text { Lackey (2011) }\end{array}$ & $\begin{array}{l}\text { Faculty were concerned about the effectiveness } \\
\text { of various forms of technology used in online } \\
\text { courses. } \\
\text { Faculty were concerned about students' technical } \\
\text { skills, their access to equipment, and their } \\
\text { abilities to use technology effectively in online } \\
\text { courses. } \\
\text { Faculty were concerned about the potential } \\
\text { for students to cheat in online courses. }\end{array}$ \\
\hline
\end{tabular}




\begin{tabular}{|c|c|c|}
\hline & $\begin{array}{l}\text { Lee, Srinivasan, Trail, } \\
\text { Lewis, \& Lopez (2011) } \\
\text { Luck \& McQuiggan (2006) } \\
\text { Mason et al. (2010) } \\
\text { Mazzolini \& Maddison } \\
\text { (2007) } \\
\text { McGee (2013) } \\
\text { Mupinga, Nora, \& Yaw } \\
\text { (2006) } \\
\text { Osika et al. (2009) } \\
\text { Ryan et al. (2005) } \\
\text { Sahin \& Shelley (2008) } \\
\text { Semple, Hatala, Franks, \& } \\
\text { Rossi (2010) } \\
\text { Stuber-McEwen, Wiseley, } \\
\text { \& Hoggatt (2009) } \\
\text { Trenholm (2007) } \\
\text { Ward, Peters, \& Shelley } \\
\text { (2010) } \\
\text { Watson \& Sottile (2010) }\end{array}$ & \\
\hline $\begin{array}{l}\text { Result } \\
\text { demonstrability }\end{array}$ & $\begin{array}{l}\text { Alsofyani et al. (2012) } \\
\text { Bacow et al. (2012) } \\
\text { Bolliger \& Wasilik (2009) } \\
\text { Chao et al. (2010) } \\
\text { Chapman (2011) } \\
\text { Christianson et al. (2002) } \\
\text { Conceição (2006) } \\
\text { DeGagne \& Walters (2010) } \\
\text { Gautreau (2011) } \\
\text { Gaytan (2009) } \\
\text { Green et al. (2009) } \\
\text { Haber \& Mills (2008) } \\
\text { Huang et al. (2011) } \\
\text { Mason et al. (2010) } \\
\text { McQuiggan (2012) } \\
\text { Orr et al. (2009) } \\
\text { Pandra \& Mishra (2007) } \\
\text { Seaman (2009) } \\
\text { Shea (2007) } \\
\text { Shea et al. (2005) } \\
\text { Wang \& Wang (2009) }\end{array}$ & $\begin{array}{l}\text { Faculty were concerned about their workload } \\
\text { in online courses. } \\
\text { Extra time to teach online was a barrier for } \\
\text { some faculty. } \\
\text { Stipends could be an incentive to teach online. } \\
\text { (No consistent compensation models for } \\
\text { faculty teaching online were identified.) } \\
\text { Flexibility was a strong incentive for faculty } \\
\text { to teach online. } \\
\text { Faculty valued professional development } \\
\text { opportunities associated with teaching online. } \\
\text { Faculty valued training, support, and mentoring } \\
\text { to help them succeed in teaching online. } \\
\text { Faculty were gratified when their online teaching was } \\
\text { recognized publicly by their institution. }\end{array}$ \\
\hline
\end{tabular}

\section{Perceived Ease of Use (PEU)}

Research has shown that PEU of educational technology affects faculty satisfaction with teaching online. Shea, Pickett, and Li (2005) surveyed 913 faculty and determined through factor 
and multiple regression analysis that technological barriers were strongly correlated to levels of online faculty satisfaction. Bolliger and Wasilik (2009) later surveyed 102 instructors and found that the issue that most impacted faculty satisfaction with teaching online was struggles with technology. A number of researchers (Bolliger \& Wasilik, 2009; Christianson, Tiene, \& Luft, 2002; Conceição, 2006; DeGagne \& Walters, 2010; Green, Alejandro, \& Brown, 2009) also found that faculty were dissatisfied if they thought that using a system would take more time or increase their workload, factors that could be considered "ease" of use, especially if users were struggling to learn how to operate a system.

Another factor that should be considered in discussions of PEU is computer self-efficacy, or a person's beliefs about his or her competence using computers (Compeau \& Higgins, 1995). Zhen, Garthwait, and Pratt (2008) determined that self-efficacy in using online course management applications effectively was the single most important factor affecting instructors' decision to adopt an application for online teaching. Other studies also showed correlations between faculty's computer self-efficacy and their intent to teach online or willingness to continue to teach online. Shea (2007) surveyed 386 faculty at 36 institutions and found that instructors who were more skilled in technology reported that they were also more willing to move new subject areas online. Similarly, Tabata and Johnsrud (2008) found in a study involving 2,048 participants that faculty's beliefs that they were skilled in using technology were significantly correlated with their intention to participate in online education. A smaller study (Osika, Johnson, \& Buteau, 2009) surveying 36 participants at an urban university in the Midwest found that the number one factor influencing faculty's decision to use an LMS to move courses online was users' previous success with other technologies. Taken together, these studies indicated that faculty's confidence about their own computer skills played a critical role in their willingness to teach online.

\section{Perceived Usefulness (PU)}

The TAM2 constructs included seven factors (subjective norm, voluntariness, experience, image, job relevance, output quality, and result demonstrability) that have been shown to affect a user's PU of a system. We found that each of these factors has been addressed in studies of faculty teaching online.

Subjective norm. The TAM2 showed that users' understanding of the value of using a system is driven in part by their perceptions about whether others in an organization feel that they should use that system. In higher education, administrators often determine who will be teaching online and what kinds of technology they might use to do so. Research suggested that administrators who communicated reasons for why faculty should teach online could create a stronger subjective norm that might encourage faculty participation in online initiatives (Betts \& Heaston, 2014; Huang et al., 2011; Wang \& Wang, 2009; Wickersham \& McElhany, 2010). Other studies noted faculty's desire for clearer institutional goals and policies concerning online education (Dooley \& Murphrey, 2000; Orr, Williams, \& Pennington, 2009) and their interest in playing a role in the development of these goals and policies (Maguire, 2009). Faculty also expressed a need for more institutional support in various forms, including enrollment caps, instructional design support, development of online faculty communities, and security or proctoring software (Chapman, 2011; Lee, 2001; Wickersham \& McElhany, 2010). These 
studies suggested that faculty satisfaction with online teaching could improve if leaders who contribute to creating the subjective norm met communication and support needs.

Voluntariness. Venkatesh and Davis (2000) found that the subjective norm had a direct effect on intention to adopt a system when using that system was mandatory, but not when it was voluntary. Some researchers found that institutions that made training for teaching online mandatory saw gains in online faculty satisfaction, even if faculty were not initially enthusiastic about using LMS (Betts, 2009; Lackey, 2011; McQuiggan, 2012). However, other researchers found differences in motivating factors to teach online, depending on whether participation was mandatory or voluntary. Some of the studies that addressed motivating instructors to teach online looked at early adopters to learn more about how to encourage other faculty to use online teaching tools (Dooley \& Murphrey, 2000; Hixon, Barczyk, Buckenmeyer, \& Feldman, 2011; Jacobsen, 2000; Shea, 2007). These studies confirmed that early adopters - most of whom volunteered to teach online - had different motivations than other faculty. For example, Shea's (2007) research involving 386 faculty at 36 institutions revealed that volunteers were more motivated by intrinsic factors (renewed passion for teaching, opportunities to experiment with new pedagogical methods, etc.), while faculty who were required to teach online were more motivated by extrinsic factors such as compensation and job security. Jacobsen (2000) also found that early adopters were driven to use technology in innovative ways; however, the majority of instructors in that study were not early adopters, and they were hesitant to use new technologies until they understood what benefits they would gain from doing so.

Experience. The TAM2 confirmed that direct experience with technology affected users' subsequent intentions to use that technology. Other research on online education reinforced this idea. Studies showed that faculty adapted well to the online environment and were more satisfied as they gained more experience. Shea et al. (2005) reported that $90 \%$ of over 900 faculty surveyed immediately after teaching an online course were satisfied with developing and delivering online courses, and almost $98 \%$ of those faculty said they would like to teach online again. Another study (Ulmer, Watson, \& Derby, 2007) surveyed 137 faculty and found significant differences in attitudes toward online education based on instructors' experience level. In this study, faculty who had more experience teaching online had significantly more positive perceptions of the overall effectiveness of instructor-student interaction and the ability to increase student performance in online courses.

Other research also revealed positive attitudes toward teaching online by faculty who had previously experienced online teaching. A survey of almost 11,000 faculty (Seaman, 2009) showed that $86.4 \%$ of faculty who were teaching an online course at the time of the survey had recommended an online course to a student. Another report by Allen and Seaman (2012a) demonstrated that faculty at institutions that offered more online courses and programs were more optimistic about online learning in general. Their survey showed that faculty who had taught online held the most positive views about it, with two-thirds of them reporting that they felt more excited than fearful about online education; in contrast, less than one-third (32.4\%) of faculty who had not taught online or blended courses viewed online education with more excitement than fear (Allen \& Seaman, 2012a). These reports suggest that, once faculty experience teaching online, they are more likely to be willing to continue to teach online courses. 
Image. Research showed that many faculty had some anxiety about how teaching online would affect their status or their prestige at a university (Allen \& Seaman, 2013; Green et al., 2009; Mason et al., 2010; Ulmer et al., 2007). Some of their concern was rooted in skepticism about the image of online education in general. For instance, in one study, almost $70 \%$ of faculty surveyed answered "No" to the question "Do you think an online degree is as prestigious as a traditional degree?” (Stewart et al., 2010).

Various studies have addressed image in terms of faculty's beliefs about whether learning outcomes in online courses were inferior to those in face-to-face classes (Allen \& Seaman, 2012a; Allen \& Seaman, 2015; Bacow et al., 2012; McQuiggan, 2012; Stewart et al., 2010). Many administrators are aware of this kind of skepticism on the part of faculty; in fact, a recent report by Allen and Seaman (2015) showed that administrators believed that online teaching has had a negative image among faculty for over a decade. Furthermore, in annual reports by Allen and Seaman since 2002, there has never been a majority of administrators who believed that their faculty accepted the "value and legitimacy of online education" (Allen \& Seaman, 2015, p. 21).

Other studies showed that faculty were concerned about whether their role as an online educator might have some bearing on their promotion or tenure (Alexander, PolyakovaNorwood, Johnston, Christensen, \& Loquist, 2003; Gaytan, 2009; Green et al., 2009; Mason et al., 2010; Orr et al., 2009; Shea, 2007). Some faculty worried that teaching online could make them more vulnerable and result in poor evaluations, thus threatening their job security (Dooley \& Murphrey, 2000; Gaytan, 2009). Junior faculty members, in particular, were apprehensive about how their courses would be assessed for quality by the institution (Shea, 2007). Clearly, faculty had concerns about their image and the effects on their career as a result of teaching online.

Job relevance. The TAM2 showed that PU was affected by job relevance, or users' perceptions of the degree to which a system might be important in their jobs by allowing them to accomplish significant goals. In online education, faculty's perceptions about using technology to engage students and accomplish learning objectives have been critical issues related to job relevance, because of the importance of student progression as a measure of success. The idea that students might learn less in online courses is an issue of image, as we have already discussed, but it is also an issue of job relevance. Studies have shown that instructors were deeply concerned about students' ability to learn in online courses (Allen \& Seaman, 2012a; Gibson et al., 2008; Osborne, Kriese, Tobey, \& Johnson, 2009; Seaman, 2009; Shovein, Huston, Fox, \& Damazo, 2005; Stewart et al., 2010). One survey of 10,700 faculty teaching online in the United States showed that $70 \%$ believed that learning outcomes for students in online courses were inferior or somewhat inferior to those experienced by students in face-to-face classes (Seaman, 2009). Another survey of 2,799 faculty and 288 campus administrators across the United States found that only $26 \%$ of faculty agreed or strongly agreed with a statement that student learning outcomes in online courses were at least equivalent to those in face-to-face ones; in contrast, $67 \%$ of campus administrators agreed or strongly agreed with that idea (Jaschik \& Lederman, 2014).

Faculty have also claimed that they valued collaboration with instructional designers who could help them design their online courses to make them more student-centric (Chao, Saj, \& 
Hamilton, 2010; DeGagne \& Walters, 2010; Johnson, 2008; McQuiggan, 2012; Ryan et al., 2005). This student-centric approach was also valued by the 10 faculty participating in a qualitative study by Orr and colleagues (2009), as all participants claimed that their major motivation in teaching online was meeting the needs of students. Clearly, in terms of job relevance, faculty were most concerned about their ability to help students thrive in an online learning environment.

Output quality. Output quality in the TAM2 concerned how well technology performed functions needed to accomplish specific tasks (Venkatesh \& Davis, 2000). Research has shown that many faculty teaching online have been concerned about various technical aspects of learning management systems (LMS) and other educational technology (Bolliger \& Wasilik, 2009; Green et al., 2009; Luck \& McQuiggan, 2006; Ryan et al., 2005; Ward, Peters, \& Shelley, 2010). Various researchers found that faculty who complained about feeling disengaged from their students did not find many forms of online communication (discussion boards, web conferencing, etc.) satisfactory for the level of interaction they desired (Arend, 2009; Haber \& Mills, 2008; Mazzolini \& Maddison, 2007; Ward et al., 2010). Some studies showed that simply accessing communication tools could be problematic, as faculty and/or students experienced issues with Internet connectivity, log-in problems, or manipulating the LMS (Lackey, 2011; Ward et al., 2010).

Another serious concern about technology among faculty teaching online has been the potential for students to cheat (Bacow et al., 2012; Chapman, Davis, Toy, \& Wright, 2004; Haber \& Mills, 2008; Trenholm, 2007). Some researchers suggested that these fears were unfounded, either because they found no significant difference between cheating in online and face-to-face classes (Grijalva, Nowell, \& Kerkvliet, 2006) or they actually found that students cheated more in face-to-face classes (Stuber-McEwen, Wiseley, \& Hoggatt, 2009; Watson \& Sottile, 2010). Even so, faculty often perceived that students had more opportunities to cheat in online courses, and some research has supported this idea (Adkins, Kenkel, \& Lim, 2005; Harmon, Lambrinos, \& Buffolino, 2010; King, Guyette, \& Piotrowski, 2009; Mason et al., 2010).

Faculty sometimes feared that students with strong technical skills could manipulate technology to their advantage, by finding technological loopholes to avoid taking tests or submitting assignments (McGee, 2013; Stuber-McEwen et al., 2009). In contrast, some instructors have worried that students might not have the technical skills to allow them to learn effectively in online environments. Various studies have shown that, even as online education has become more prevalent, students' essential technical skills for online learning have varied widely (Arif, 2001; Lee, Srinivasan, Trail, Lewis, \& Lopez, 2011; Sahin \& Shelley, 2008). Indeed, instructors' concerns about students' technical skills are output quality issues, since students' abilities to use technologies are essential for those technologies to be effective.

Result demonstrability. Result demonstrability, or perceived tangible results and benefits of using a technological system, also affected PU in the TAM2. A number of studies have noted benefits that faculty have received or would like to receive as a result of teaching online. The most obvious tangible results for employees are related to money and time. Issues of compensation, time, and workload have recurred throughout the literature on online teaching. In 
fact, Bolliger and Wasilik (2009) found that some of the most significant institutional issues affecting faculty satisfaction were a higher workload and increased time commitment for online instructors. Many other studies have acknowledged issues of substantial time commitments and workload for online faculty (Bacow et al., 2012; Christianson et al., 2002; Conceição, 2006; DeGagne \& Walters, 2010; Green et al., 2009; Haber \& Mills, 2008; Mason et al., 2010). Most research has shown that time commitment and workload were barriers or demotivators to faculty, though some studies claimed that the extra time commitment did not affect faculty satisfaction or preference for teaching online (Christianson et al., 2002; Orr et al., 2009; Shea et al., 2005). Some researchers also determined that faculty would not mind the extra time it took to deliver online courses if they were adequately compensated (Haber \& Mills, 2008; Huang et al., 2011; Shea, 2007).

Many studies have cited one main factor that played a role in faculty's satisfaction with online education: the flexibility of teaching online courses. Recurring throughout the reviewed studies was the idea that faculty appreciated the fact that online education was not bound by time or space. For example, Shea's (2007) survey of 386 faculty teaching online in 36 colleges found that the top motivator was a flexible work schedule. Similarly, Green et al. (2009) determined that $82.22 \%$ of 135 faculty they surveyed claimed they enjoyed the flexibility of online instruction. Additional research by Chapman (2011) included full-time and part-time instructors; the author surveyed 294 tenured/tenure-track and adjunct instructors and found that the strongest motivation for both groups to teach online was a flexible schedule.

A variety of tangible rewards for instructors teaching online was found to be an effective means to attract faculty to teach online. For example, some researchers discovered that faculty viewed new technologies positively because learning about them was a professional development opportunity or a way to grow intellectually (Chapman, 2011; Green et al., 2009; McQuiggan, 2012; Pandra \& Mishra, 2007; Seaman, 2009). Faculty also appreciated access to high-quality training and support programs and other forms of mentoring to help them be successful teaching online (Alsofyani et al., 2012; Chao et al., 2010; Chapman, 2011; Green et al., 2009; McQuiggan, 2012; Shea et al., 2005; Wang \& Wang, 2009). Other studies showed that instructors were motivated when their achievements in teaching online were highlighted or recognized with an award by their institution (Bacow et al., 2012; Gautreau, 2011; Mason et al., 2010). In general, faculty in these studies expressed that teaching online afforded them opportunities for professional growth and allowed them more control over their own schedules.

\section{Conclusions}

Even though we initially found few studies applying the TAM or the TAM2 to faculty acceptance of technology for online teaching, this literature review revealed that researchers have addressed various elements of the TAM2 in terms of faculty teaching online. Table 1 shows a myriad of issues, attitudes, and concerns aligning with TAM2 constructs that our reviewed studies addressed in different ways. Exploring these empirical studies in this context provided a lens to better understand faculty perceptions, not only of the user-friendliness and usefulness of technological tools, but of the overall experience of teaching online. This synthesis is important, since recognizing faculty's needs and desires in their roles as instructors is critical for institutions offering online courses and programs. In addition, understanding more about how faculty accept 
and implement technology used for online learning could help higher education administrators promote positive attitudes and support faculty efforts to foster student success in online courses.

Some studies in this review indicated a gap between views of administrators and faculty concerning the usefulness of online education. Instructors were particularly concerned about issues affecting student success, such as effective communication, technical proficiency, and legitimate achievement of learning outcomes without cheating. Faculty also were concerned about their own status as online instructors in the larger institutional culture. Some instructors worried about how teaching online would affect their image. Instructors were also unsure about how their online teaching would be evaluated, particularly in promotion and tenure processes. Issues of time commitment and workload were viewed as barriers to teaching online as well.

At the same time, many of the studies showed that instructors adapted well to the online environment as they gained more experience. Faculty who were teaching online were gratified when institutions provided mentoring, training, support, and recognition of their success. Instructors also valued the personal and professional rewards that resulted from their online teaching, such as flexible schedules and professional development opportunities. The reviewed studies also found that, whether or not they were already teaching online, faculty's perceptions about the user-friendliness of technology and their own skills in mastering LMS and other tools played a role in their satisfaction with online teaching and learning.

This review also highlighted gaps in research concerning faculty's experiences in teaching online. The TAM2 provided a well-defined framework for understanding faculty perceptions, and more research that directly applies the TAM2 to faculty teaching online is warranted. Further studies could also shed more light on faculty's perceptions of how teaching online would help them achieve their goals (job relevance) and accomplish essential tasks (output quality). More research could also help administrators understand how to communicate the value of online education to faculty in terms that resonate with them. Exploring more about potential tangible benefits for faculty teaching online (result demonstrability) could also help institutions address issues of compensation and workload.

The knowledge gleaned from this literature review has significant implications for institutions that seek to build and maintain strong online programs. Knowing more about faculty's views about the user-friendliness of technology used to teach online (including LMS, web conferencing tools, or other technology used for communicating or delivering content via the Internet) could help universities determine how to train faculty to teach in their online courses and programs. It is also important to understand more about faculty's computer selfefficacy to assist them in using technologies to their fullest potential. Administrators who determine teaching assignments and cap class enrollments could address barriers such as time commitment and workload for online teaching. Academic leaders responsible for strategic plans could also involve faculty in planning processes and clearly communicate institutional mission and goals for their online programs.

Using the TAM2 as a framework to explore research on faculty satisfaction with teaching online also highlighted important factors for institutions to consider if they want their faculty to thrive in online teaching and learning environments. The various facets of the model provide 
guideposts for universities to focus on in recruiting and retaining online instructors. Understanding faculty's computer self-efficacy could help institutions plan what kind of training programs would be needed to encourage more instructors to teach online. Recognizing the need for continuous training and support, even for experienced instructors, could convince administrators to leverage resources to provide these kinds of programs. Indeed, academic leaders who are aware of the effects of social influence processes could use their power to change institutional culture. By consistently supporting faculty and demonstrating to them that their efforts are just as valuable as those of instructors teaching face-to-face, administrators could create a strong positive image of online education at their institution.

\section{References}

Adkins, J., Kenkel, C., \& Lim, C. (2005). Deterrents to online academic dishonesty. The Journal of Learning in Higher Education, 1(1), 17-22. Retrieved from http://jwpress.com/JLHE/Issues/v1i1/Deterrents\%20to\%20Online\%20Academic\%20Dis honesty.pdf

Alexander, J., Polyakova-Norwood, V., Johnston, L., Christensen, P., \& Loquist, R. (2003). Collaborative development and evaluation of an online nursing course. Distance Education, 24(1), 41-56. doi:10.1080/01587910303046

Allen, I. E. \& Seaman, J. (2012a). Conflicted: Faculty and online education. Babson Survey Research Group and Quahog Research Group, LLC. Retrieved from http://www.insidehighered.com/sites/default/server_files/files/IHE-BSRG-Conflict.pdf

Allen, I. E. \& Seaman, J. (2012b). Digital faculty: Professors, teaching and technology, 2012. Babson Survey Research Group and Quahog Research Group, LLC. Retrieved from https://www.insidehighered.com/sites/default/server_files/DigitalFaculty.htm

Allen, I. E. \& Seaman, J. (2013). Changing course: Ten years of tracking online education in the United States. Babson Survey Research Group and Quahog Research Group, LLC. Retrieved from http://www.onlinelearningsurvey.com/reports/changingcourse.pdf

Allen, I. E., \& Seaman, J. (2015). Grade level: Tracking online education in the United States. Babson Survey Research Group and Quahog Research Group, LLC. Retrieved from http://www.onlinelearningsurvey.com/reports/gradelevel.pdf

Alsofyani, M., Aris, B., Eynon, R., \& Majid, N. (2012). A preliminary evaluation of short blended online training workshop for TPACK development using technology acceptance model. The Turkish Online Journal of Educational Technology, 11(3), 20-32. Retrieved from http://www.tojet.net/articles/v11i3/1133.pdf 
Arend, B. (2009). Encouraging critical thinking in online threaded discussions. The Journal of Educators Online, 6(1). Retrieved from http://www.thejeo.com/Archives/Volume6Number1/Arendpaper.pdf

Arif, A. (2001). Learning from the web: Are students ready or not? Educational Technology \& Society, 4(4), 32-38. Retrieved from http://www.ifets.info/others/journals/4_4/arif.html

Bacow, L., Bowen, W., Guthrie, K., Lack, K., \& Long, M. (2012). Barriers to adoption of online learning systems in U.S. higher education. Ithaka S+R Consulting. Retrieved from http://www.sr.ithaka.org/research-publications/barriers-adoption-online-learningsystems-us-higher-education

Betts, K. (2009). Online Human Touch (OHT) training \& support: A conceptual framework to increase faculty engagement, connectivity, and retention in online education, part 2. Journal of Online Learning and Teaching, 5(1). Retrieved from http://jolt.merlot.org/vol5no1/betts_0309.htm

Betts, K., \& Heaston, A. (2014). Build it but will they teach? Strategies for increasing faculty participation and retention in online and blended education. Online Journal of Distance Learning Administration, 17, (2). Retrieved from http://www.westga.edu/ distance/ojdla/summer172/betts_heaston172.html

Bolliger, D., \& Wasilik, O. (2009). Factors influencing faculty satisfaction with online teaching and learning in higher education. Distance Education, 30(1), 103-116.

doi:10.1080/01587910902845949

Chao, I., Saj, T., \& Hamilton, D. (2010). Using collaborative course development to achieve online course quality standards. International Review of Research in Open and Distributed Learning, 11(3), 106-126. Retrieved from http://www.irrodl.org/index.php/irrodl/article/view/912

Chapman, D. (2011). Contingent and tenured/tenure-track faculty: Motivations and incentives to teach distance education courses. Online Journal of Distance Learning Administration, 14(3), 1-15. Retrieved from http://www.westga.edu/ distance/ojdla/fall143/chapman143.html

Chapman, K., Davis, R., Toy, D., \& Wright, L. (2004). Academic integrity in the business school environment: I'll get by with a little help from my friends. Journal of Marketing Education, 26(3), 236-249. doi:10.1177/0273475304268779

Christianson, L., Tiene, D., \& Luft, P. (2002). Web-based teaching in undergraduate nursing programs. Nurse Educator, 27(6), 276-282. doi:10.1097/00006223-200211000-00009

Compeau, D., \& Higgins, C. (1995). Computer self-efficacy: Development of a measure and initial test. MIS Quarterly, 19(2), 189-211. doi:10.2307/249688 
Conceição, S. (2006). Faculty lived experiences in the online environment. Adult Education Quarterly, 57(1), 26-45. doi:10.1177/1059601106292247

Davis, F. (1989). Perceived usefulness, perceived ease of use, and user acceptance of information technology. MIS Quarterly, 13(3), 319-340. doi:10.2307/249008

Davis, F. (1993). User acceptance of information technology: System characteristics, user perceptions and behavioral impacts. International Journal of Man-Machine Studies, 38, 475-487. doi:10.1006/imms.1993.1022

DeGagne, J., \& Walters, K. (2010). The lived experience of online educators: Hermeneutic phenomenology. Journal of Online Learning and Teaching, 6(2). Retrieved from http://jolt.merlot.org/vol6no2/degagne_0610.htm

Dooley, K., \& Murphrey, T. P. (2000). How the perspectives of administrators, faculty and support units impact the rate of distance education adoption. Online Journal of Distance Learning Administration, 3(4). Retrieved from http://www.westga.edu/ distance/ojdla/winter34/dooley34.html

Gautreau, C. (2011). Motivational factors affecting the integration of a learning management system by faculty. The Journal of Educators Online, 8(1). Retrieved from http://files.eric.ed.gov/fulltext/EJ917870.pdf

Gaytan, J. (2009). Analyzing online education through the lens of institutional theory and practice: The need for research-based and -validated frameworks for planning, designing, delivering, and assessing online instruction. The Journal of Research in Business Education, 51(2), 62-75. Retrieved from http://www.dpe.org/publications.htm

Gibson, S., Harris, M., \& Colaric, S. (2008). Technology acceptance in an academic context: Faculty acceptance of online education. Journal of Education for Business, 83(6), 355359. doi:10.3200/JOEB.83.6.355-359

Green, T., Alejandro, J., \& Brown, A. (2009). The retention of experienced faculty in online distance education programs: Understanding factors that impact their involvement. The International Review of Research in Open and Distance Learning, 10(3), 1-15. Retrieved from http://www.irrodl.org/index.php/irrodl/article/view/683/1279

Grijalva, T., Nowell, C., \& Kerkvliet, J. (2006). Academic honesty and online courses. College Student Journal, 40(1), 180-185. Retrieved from http://www.projectinnovation.com/college-student-journal.html

Haber, J., \& Mills, M. (2008). Perceptions of barriers concerning effective online teaching and policies: Florida community college faculty. Community College Journal of Research and Practice, 32, 266-283. doi:10.1080/10668920701884505 
Hagedorn, L.S. (2000). Conceptualizing faculty job satisfaction: Components, theories, and outcomes. New Directions for Institutional Research, 2000(105), 5-20. doi:

10.1002/ir.10501

Harmon, O., Lambrinos, J., \& Buffolino, J. (2010). Assessment design and cheating risk in online instruction. Online Journal of Distance Learning Administration, 13(3). Retrieved from http://www.westga.edu/ distance/ojdla/Fall133/harmon_lambrinos_buffolino133.html

Hixon, E., Barczyk, C., Buckenmeyer, J., \& Feldman, L. (2011). Mentoring university faculty to become high quality online educators: A program evaluation. Online Journal of Distance Learning Administration, 14(5). Retrieved from http://distance.westga.edu/ distance/ojdla/winter144/hixon_Barczyk_Buckenmeyer_feld man144.html

Huang, R.T., Deggs, D. M., Jabor, M. K., \& Machtmes, K. (2011). Faculty online technology adoption: The role of management support and organizational climate. Online Journal of Distance Learning Administration, 14(2). Retrieved from http://www.westga.edu/ distance/ojdla/summer142/huang_142.html

Jacobsen, D. M. (2000). Examining technology adoption patterns by faculty in higher education. Proceedings of ACEC2000: Learning Technologies, Teaching and the Future of Schools, July 6 to 9, Melbourne, Australia. Retrieved from http://people.ucalgary.ca/ dmjacobs/acec/

Jaschik, S., \& Lederman, D. (2014). The 2014 Inside Higher Ed survey of faculty attitudes on technology. Gallup and Inside Higher Ed. Retrieved from https://www.insidehighered.com/node/71103/download/3543a7f4860331d55489c20b4f6f a059

Johnson, A. (2008). A nursing faculty’s transition to teaching online. Nursing Education Perspectives 29(1), 17-22. Retrieved from http://www.nln.org/nlnjournal/

King, C., Guyette, R., \& Piotrowski, C. (2009). Online exams and cheating: An empirical analysis of business students' views. The Journal of Educators Online, 6(1). Retrieved from http://www.thejeo.com/Archives/Volume6Number1/Kingetalpaper.pdf

King, W., \& He, J. (2006). A meta-analysis of the technology acceptance model. Information \& Management, 43(6), 740-755. doi:10.1016/j.im.2006.05.003

Lackey, K. (2011). Faculty development: An analysis of current and effective training strategies for preparing faculty to teach online. Online Journal of Distance Learning Administration, 14(5). Retrieved from http://www.westga.edu/ distance/ojdla/winter144/lackey144.html 
Lee, J. (2001). Instructional support for distance education and faculty motivation, commitment, satisfaction. British Journal of Educational Technology, 32(2), 153-160.

doi:10.1111/1467-8535.00186

Lee, S., Srinivasan, S., Trail, T., Lewis, D., \& Lopez, S. (2011). Examining the relationship among student perception of support, course satisfaction, and learning outcomes in online learning. Internet \& Higher Education, 14(3), 158-163. doi:10.1016/j.iheduc.2011.04.001

Luck, A., \& McQuiggan, C. (2006). Discovering what faculty really need to know about teaching online. Proceedings of the $22^{\text {nd }}$ Annual Conference on Distance Teaching \& Learning, August 2-6. Madison, WI. Retrieved from http://www.uwex.edu/disted/conference/Resource_library/proceedings/06_4160.pdf

Maguire, L. (2009). The faculty perspective regarding their role in distance education policy making. Online Journal of Distance Learning Administration, 12(1). Retrieved from http://www.westga.edu/ distance/ojdla/spring121/maguire121.html

Marangunić, N., \& Granić, A. (2015). Technology acceptance model: a literature review from 1986 to 2013. Universal Access in the Information Society, 14: 81-95. doi: 10.1007/s10209-014-0348-1

Mason, J., Hickman, C., Dyer, A., Koproske, C., Fry, G., \& Taha, M. (2010). Engaging faculty in online education: Rightsizing incentives and optimizing support. Washington, DC: University Leadership Council of The Advisory Board Company. Retrieved from http://www20.csueastbay.edu/oaa/files/student_success/EngFacOnlineEd.pdf

Mazzolini, M., \& Maddison, S. (2007). When to jump in: The role of the instructor in online discussion forums. Computers \& Education, 49(2), 193-213. Retrieved from doi:10.1016/j.compedu.2005.06.011

McGee, P. (2013). Supporting academic honesty in online courses. Journal of Educators Online, 10(1). Retrieved from http://www.thejeo.com/Archives/Volume10Number1/McGee.pdf

McQuiggan, C. (2012). Faculty development for online teaching as a catalyst for change. Journal of Asynchronous Learning Networks, 16(2), 27-61. Retrieved from http://files.eric.ed.gov/fulltext/EJ971044.pdf

Mupinga, D., Nora, R., \& Yaw, D. (2006). The learning styles, expectations, and needs of online students. College Teaching, 54(1), 185-189. doi:10.3200/CTCH.54.1.185-189

Orr, R., Williams, M., \& Pennington, K. (2009). Institutional efforts to support faculty in online teaching. Innovative Higher Education, 34(4), 257-268. doi:10.1007/s10755-009-9111-6

Osborne, R., Kriese, P., Tobey, H., \& Johnson, E. (2009). And never the two shall meet? Student vs. faculty perceptions of online courses. Journal of Educational Computing Research, 40(2), 171-182. doi:10.2190/EC.40.2.b 
Osika, E., Johnson, R., \& Buteau, R. (2009). Factors influencing faculty use of technology in online instruction: A case study. Online Journal of Distance Learning Administration, 12(1). Retrieved from http://www.westga.edu/ distance/ojdla/spring121/osika121.html

Panda, S., \& Mishra, S. (2007). E-learning in a mega open university: Faculty attitude, barriers and motivators. Educational Media International, 44(4), 323-338.

doi:10.1080/09523980701680854

Ryan, M., Hodson-Carlton, K., \& Ali, N. (2005). A model for faculty teaching online: Confirmation of a dimensional matrix. Journal of Nursing Education, 44(8), 357-365. Retrieved from http://www.nottingham.ac.uk/ ntzcl1/literature/teaching/ryan-2005.pdf

Sahin, I., \& Shelley, M. (2008). Considering students’ perceptions: The distance education student satisfaction model. Educational Technology \& Society, 11(3), 216-223. Retrieved from http://ifets.info/journals/11_3/15.pdf

Seaman, J. (2009). "Volume II: The paradox of faculty voices: Views and experiences with online learning.” In “Online learning as a strategic asset: Results of a national faculty survey," part of the online education benchmarking study conducted by the APLU Sloan National Commission on Online Learning. Retrieved from http://olc.onlinelearningconsortium.org/publications/survey/APLU_Reports

Semple, M., Hatala, J., Franks, P., \& Rossi, M. (2010). Is your avatar ethical? On-line course tools that are methods for student identity and verification. Journal of Educational Technology Systems, 39(2), 181-191. doi:10.2190/ET.39.2.h

Shea, P. (2007). Bridges and barriers to teaching online college courses: A study of experienced online faculty at 36 colleges. Journal of Asynchronous Learning Networks, 11(2), 73128. Retrieved from http://www.sunyresearch.net/hplo/?page_id=13

Shea, P., Pickett, A., \& Li, C. (2005). Increasing access to higher education: A study of the diffusion of online teaching among 913 college faculty. The International Review of Research in Open and Distance Learning, 6(2). Retrieved from http://www.irrodl.org/index.php/irrodl/article/view/238

Shovein, J., Huston, C., Fox, S., \& Damazo, B. (2005). Challenging traditional teaching and learning paradigms: Online learning and emancipatory teaching. Nursing Education Perspectives, 26(6), 340-343. Retrieved from http://www.nln.org/nlnjournal/

Stewart, C., Bachman, C., \& Johnson, R. (2010). Predictors of faculty acceptance of online education. MERLOT Journal of Online Learning and Teaching, 6(3), 597-616. Retrieved from http://jolt.merlot.org/vol6no3/stewartc_0910.pdf

Stuber-McEwen, D., Wiseley, P. \& Hoggatt, S. (2009). Point, click, and cheat: Frequency and type of academic dishonesty in the virtual classroom. Online Journal of Distance 
Learning Administration, 12(3). Retrieved from

http://www.westga.edu/ distance/ojdla/fall123/stuber123.html

Tabata, L., \& Johnsrud, L. (2008). The impact of faculty attitudes toward technology, distance education, and innovation. Research in Higher Education, 49(7), 625-646.

doi:10.1007/s11162-008-9094-7

Trenholm, S. (2007). A review of cheating in fully asynchronous online courses: A math or factbased course perspective. Journal of Educational Technology Systems, 35(3), 281-300. doi:10.2190/Y78L-H21X-241N-7Q02

Ulmer, L., Watson, L., \& Derby, D. (2007). Perceptions of higher education faculty members on the value of distance education. The Quarterly Review of Distance Education, 8(1), 5970. Retrieved from http://faculty.weber.edu/eamsel/Research\%20Groups/Online\%20Learning/Umer\%20et\%20al.\%20\%282007\%29.pdf

Venkatesh, V., \& Davis, F. (1996). A model of the antecedents of perceived ease of use: Development and test. Decision Sciences, 27(3), 451- 481. doi:10.1111/j.15405915.1996.tb00860.x

Venkatesh, V., \& Davis, F. (2000). A theoretical extension of the technology acceptance model: Four longitudinal field studies. Management Science, 46(2), 186-204. doi:10.1287/mnsc.46.2.186.11926

Wang, W., \& Wang, C. (2009). An empirical study of instructor adoption of web-based learning systems. Computers \& Education, 53(3), 761-774. doi:10.1016/j.compedu.2009.02.021

Ward, M., Peters, G., \& Shelley, K. (2010). Student and faculty perceptions of the quality of online learning experiences. International Review of Research in Open \& Distance Learning, 11(3), 57-77. Retrieved from http://www.irrodl.org/index.php/irrodl/article/view/867

Watson, G., \& Sottile, J. (2010). Cheating in the digital age: Do students cheat more in online courses? Online Journal of Distance Learning Administration, 13(1). Retrieved from http://www.westga.edu/ distance/ojdla/spring131/watson131.html

Wickersham, L., \& McElhany, J. (2010). Bridging the divide: Reconciling administrator and faculty concerns regarding online education. Quarterly Review of Distance Education, 11(1), 1-12. Retrieved from http://www.infoagepub.com/quarterly-review-of-distanceeducation.html

Zhen, Y., Garthwait, A., \& Pratt, P. (2008). Factors affecting faculty members' decision to teach or not to teach online in higher education. Online Journal of Distance Learning Administration, 11(3). Retrieved from http://www.westga.edu/ distance/ojdla/fall113/zhen113.html 